\title{
LATE WEICHSELIAN HISTORY OF RELATIVE SEA LEVEL CHANGES IN ICELAND DURING A COLLAPSE AND SUBSEQUENT RETREAT OF MARINE BASED ICE SHEET
}

\author{
H.G. PÉTURSSON ${ }^{*}$, H. NORĐDAHL ${ }^{2}$, \\ Ó. INGÓLFSSON ${ }^{2}$
}

\footnotetext{
${ }^{1}$ Icelandic Institute of Natural History, Borgir við Norðurslóð, IS-600 Akureyri, Iceland. ${ }^{2}$ University of Iceland, Institute of Earth Sciences, Askja, Sturlugata 7, IS-101 Reykjavík, Iceland.
}

\begin{abstract}
At the Last Glacial Maximum, Iceland was covered by an ice sheet more than $2000 \mathrm{~m}$ thick reaching as far as the shelf break. Rapid deglaciation, controlled by rising global sea level, started between 18.6 and 15.0 cal kyrs BP. In Bølling times, between 15.0 and 14.7 cal kyrs BP, the marine based part of the ice sheet collapsed and glaciers retreated inside the present coastline. At that time Marine Limit (ML) shorelines at very high altitudes were formed. Due to low viscosity of the mantel underneath Iceland, isostatic recovery was very rapid and there is a clear link between deglaciation, glacial unloading and volcanic activity. Following climatic deterioration the ice sheet re-advanced during the Younger Dryas, between 13.8 and 12.0 cal kyrs BP. The advance was terminated near the present coastline as distinct shorelines at lower altitudes than before were formed. In Early Preboreal times, about 11.2 cal kyrs BP, the ice sheet readvanced once again and a new set of distinct shorelines was formed, at still lower altitudes than before. After that the ice sheet retreated rapidly and relative sea level fell towards and eventually below present sea level, reaching a minimum at $-44 \mathrm{~m}$ at about 10.0 cal kyrs BP. At about 8.7 cal kyrs BP the ice sheet had disintegrated into individual icecaps of similar extent as the present glaciers.
\end{abstract}

Cambios relativos del nivel del mar en Islandia a finales del Weichseliense durante el colapso y consiguiente retirada del manto de hielo marino

RESUMEN. A finales del Último Máximo Glacial, Islandia estaba cubierta por una capa de hielo de más de 2000 m de espesor, llegando hasta la ruptura de la plataforma continental. Una deglaciación rápida, controlada por el ascenso global del nivel del mar, comenzó entre 18,6 y 15,0 cal kyrs BP. Durante el B $\phi l l i n g$, entre 15,0 y 14,7 cal kyrs BP, la parte marina del manto de hielo colapsó y los glaciares se retiraron al interior de la actual línea de costa. En ese momento se formaron líneas de playa correspondientes al Límite Marino a elevadas alturas. Debido a la baja viscosidad del manto por debajo de Islandia, la recuperación 
isostática fue muy rápida, de manera que hay una estrecha relación entre deglaciación, descarga glacial y actividad volcánica. Después del deterioro climático, la capa de hielo experimentó un reavance durante el Younger Dryas, entre 13,8 y 12,0 cal kyrs BP. El avance terminó cerca de la costa actual, pues se formaron distintas líneas de playa a menores alturas que las anteriores. A comienzos del Preboreal, hacia 11,2 cal kyrs BP, la capa de hielo tuvo un nuevo reavance, formándose un nuevo conjunto de líneas de costa, a alturas todavía inferiores que las anteriores. Después el hielo se retiró rápidamente y el nivel del mar relativo cayó hasta e incluso por debajo de actual nivel del mar, alcanzando un mínimo de -44 m hacia 10,0 cal kyrs BP. Hacia 8,7 cal kyrs BP el manto de hielo se desintegró en casquetes individuales de extensión similar a los actuales glaciares.

Key words: Iceland, ice sheet, Weichselian, deglaciation, sea level.

Palabras clave: Islandia, manto de hielo, Weichseliense, deglaciación, nivel del mar.

Received 6 April 2015

Accepted 20 April 2015

*Corresponding author: Icelandic Institute of Natural History, Borgir við Norðurslóð, IS-600 Akureyri, Iceland. E-mail: hgp@ni.is

\section{Introduction and terminology}

This paper gives a brief overview of the history of relative sea level changes, deglaciation and environmental changes in Iceland since the Last Glacial Maximum (LGM) and it is primarily based on reviews by Norðdahl and Pétursson (2005) and Norðdahl et al. (2008).

In our chronology, ${ }^{14} \mathrm{C}$ dates on marine shells are reservoir corrected by $365 \pm 20$ ${ }^{14} \mathrm{C}$ years $[\Delta R=24 \pm 23]$, the apparent age for living marine organisms around Iceland (Håkansson, 1983). Weighted mean age and standard deviation of dated samples are obtained with the Radiocarbon Calibration Program (CALIB) Rev. 7.0.2 (Stuvier and Reimer, 1993). Age of terrestrial material is calibrated with the data set Intcal13 (Reimer et al., 2013), and marine material with the data set Marine13 (Reimer et al., 2013). In this paper ages are reported as calibrated (kilo-) years before present (cal (k)yrs BP = 1950 AD) and all essential dates are listed in Table 1 with references to their original publication. This paper follows the chronostratigraphical terminology for Norden as proposed by Mangerud et al. (1974). 


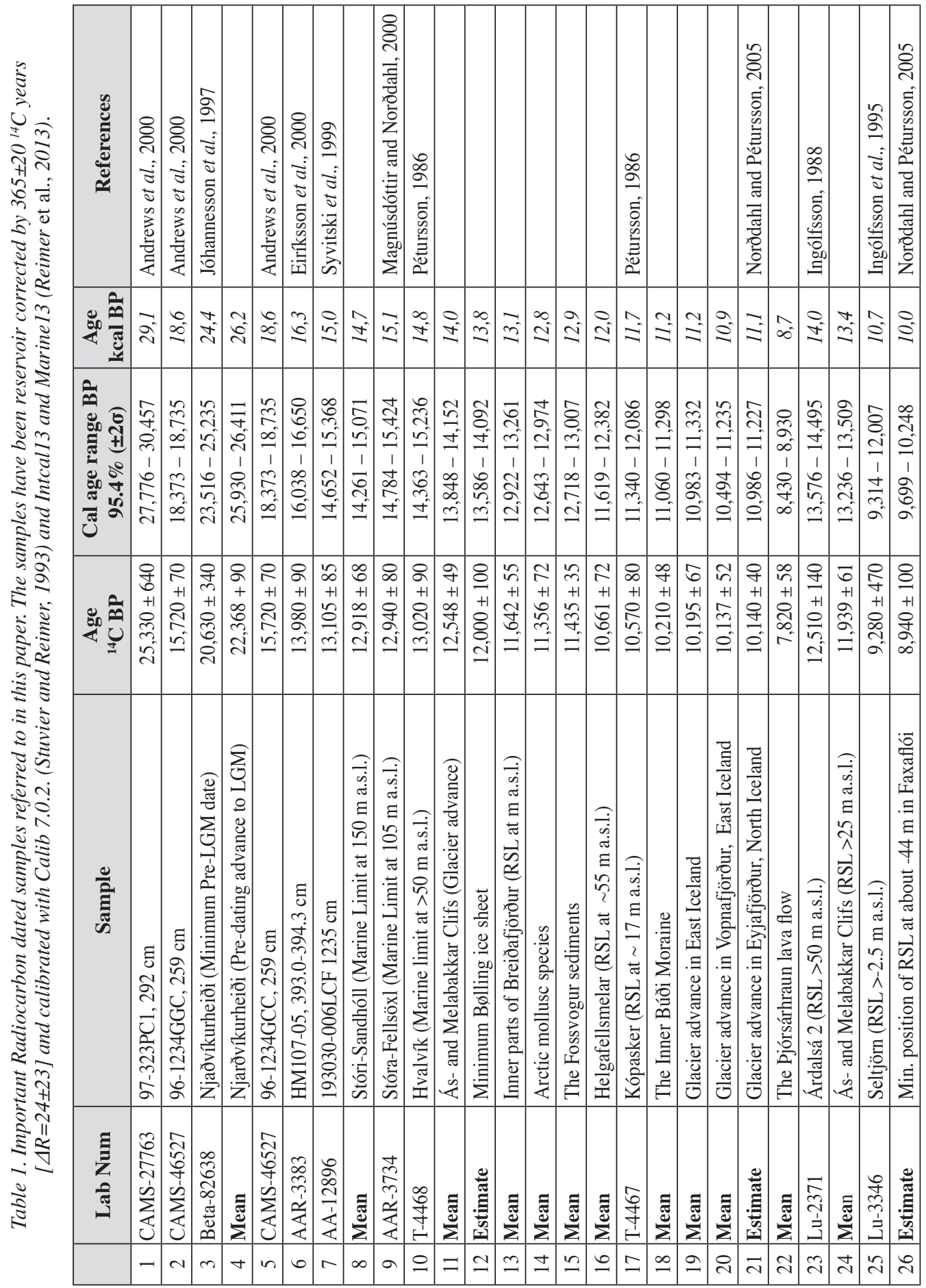




\section{The Icelandic LGM ice sheet}

Geomorphological data like glacial striae, extent of glacial deposits and landforms, as well as glacial diamictons and terminal moraines on the shelf, show that Iceland was covered by an extensive ice sheet during the LGM (Fig. 1). Tills and striae on the island of Grímsey, $40 \mathrm{~km}$ off North Iceland, show that the LGM ice sheet reached and overrode the island (Einarsson, 1967; Norðdahl, 1991). A $100 \mathrm{~km}$ long and up to $50 \mathrm{~m}$ high ridge, thought to be a terminal moraine at 200-350 m below sea level on the shelf some $130 \mathrm{~km}$ west off the Breiðafjörður inlet in West Iceland, most likely marks the LGM extent of the Icelandic ice sheet (Ólafsdóttir, 1975; Syvitsky et al., 1999). Submarine landforms and geophysical and bathymetric data showing position and extent of apparent end and terminal moraines as well as lateral extent and thickness of glacigenic and nonglacigenic sediment accumulations, have been used for confining the LGM ice sheet on the shelf off Southwest, West, Northwest and North Iceland, reviewed in Norðdahl and Pétursson (2005). Spagnolo and Clark (2009) have analysed data from the Olex database and recognized moraines on the shelf around Iceland, much in agreement with earlier research. Off East Iceland they recognized distinct "trough moraine" close to the shelf break about $100 \mathrm{~km}$ off East Iceland (Fig. 1). Off South-eastern Iceland Thors and Helgadóttir (2014) recently described a possible LGM terminal moraine in Lónsdjúp, some $100 \mathrm{~km}$ off the south-eastern coast (Fig. 1).

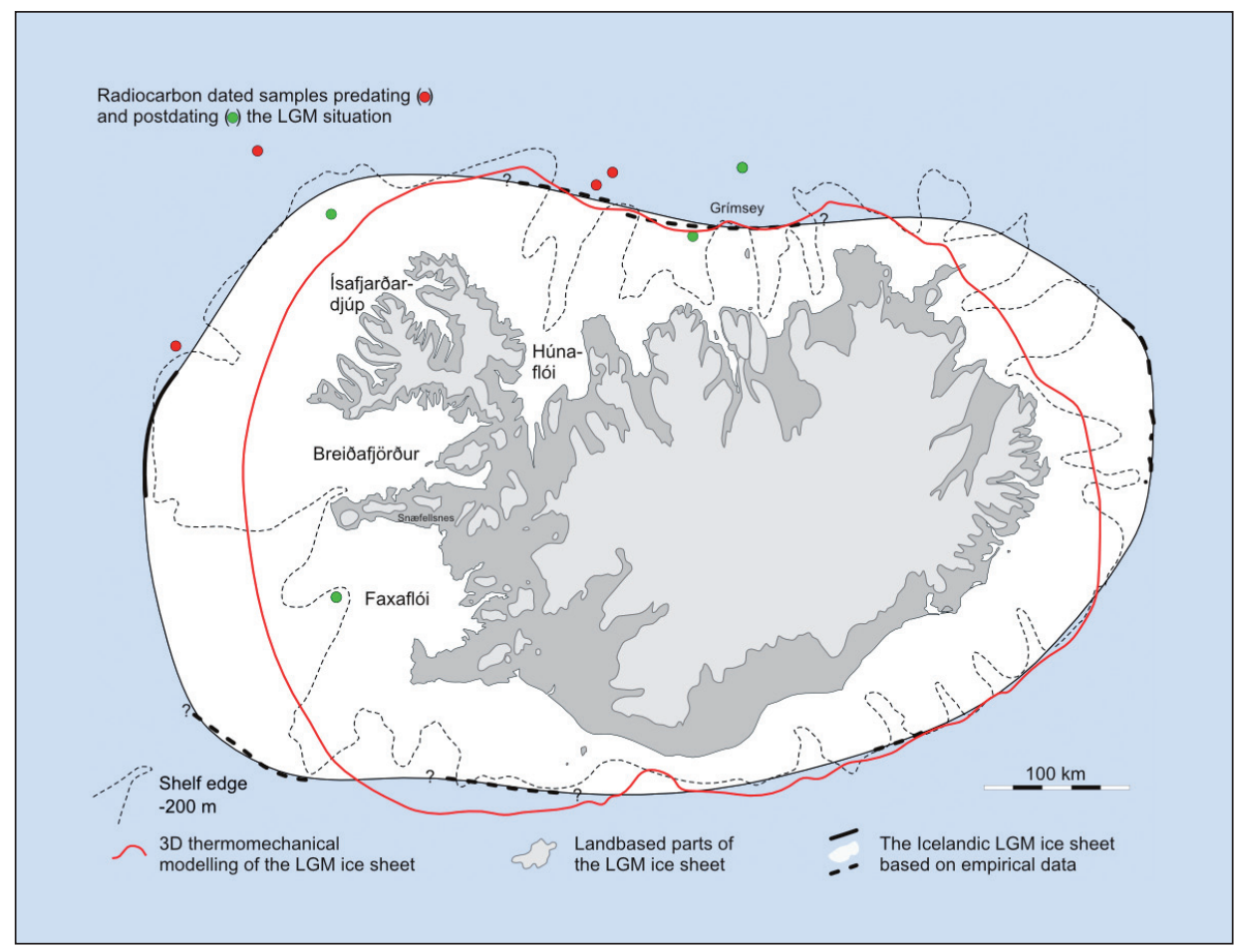

Figure 1. The Icelandic ice sheet at LGM. (Modified from Norðdahl et al., 2008). 
On land, glacial striae and erratics on top of high mountains, relative height of tablemountains, lip-elevation of corries, frost shattering on top of high coastal mountains, and orientation of glacial striae and other linear landforms have been used to infer temporary thickness and flow of the ice sheet. The LGM configuration of the Icelandic ice sheet (Fig. 1) is based on a synthesis by Norðdahl and Pétursson (2005) and three-dimensional thermomechanical modelling by Hubbard et al. (2006), adopted by Norðdahl et al. (2008). Calculations by Hubbard et al. (2006) suggest that the Icelandic LGM ice sheet, was more than $2000 \mathrm{~m}$ thick in its central parts, with a surface area of about $330 \cdot 10^{3} \mathrm{~km}^{2}$ and a substantial marine component $(\sim 63 \%)$ i.e. ice grounded below relative sea level at that time (Fig. 1). In LGM times the ice sheet probably contained more than $300 \cdot 10^{3} \mathrm{~km}^{3}$ of ice (Hubbard et al. 2006). It is still unclear whether some elements of the Icelandic flora and fauna may have survived the Weichselian glaciation in ice-free coastal enclaves (Rundgren and Ingólfsson, 1999).

Sediment cores from the shelf off West and North Iceland (Fig. 1) have provided samples and calibrated radiocarbon dates that constrain the LGM situation on the shelf around Iceland, dates older than 29.1 cal kyrs BP pre-date the LGM situation while dates younger than 18.6 cal kyrs BP post-date the LGM situation on the Iceland shelf (Table 1;1-2) (Andrews et al., 2000). As there is a significant difference between these dates post and pre-dating the LGM situation we conclude that it was reached on the Iceland shelf sometimes between 29.1 and 18.6 cal kyrs BP.

This is supported by data from land, in the area around Keflavík in Southwest Iceland, where seven samples of marine shells have yielded a weighted mean age of $26.2 \mathrm{cal}$ kyrs BP with a minimum date of about 24.4 cal kyrs BP (Table 1;4-3) (Norðdahl and Pétursson, 2005). These sediments pre-date a glacier advance towards a LGM position west off Southwest Iceland and our conclusion is that the LGM situation on the shelf off West Iceland most likely occurred at about or a little later than 24.4 cal kyrs BP.

\section{Mantel characteristics below Iceland and glacio-isostatic uplift}

Iceland is the largest land area of the mid-ocean ridge system and has been built up by excessive volcanism caused by interaction of a mantel plume and a mid-oceanic ridge. The mantel in the vicinity of the North Atlantic mantel plume is known for low viscosity, which has been used to explain rapid isostatic recovery at the end of the last glaciation. Concurrently a large pulse occurred in the volcanic activity and production in Iceland, suggesting a clear link between deglaciation, glacial unloading and volcanism (Sigmundson, 1991, 2006; Slater et al., 1998; Maclennan et al., 2002; Sigvaldason, 2002; Norðdahl and Pétursson, 2005; Licciardi et al., 2007).

In same way as retreat of the Icelandic ice sheet caused rapid rise of the crust in late Weichselian times, advancing glaciers and increasing glacier load caused subsidence of the crust. Consequently transgressions in Iceland have been interpreted to signify both rise of eustatic sea level and subsidence of the Icelandic crust caused by expansion of the Icelandic ice sheet (Norðdahl and Pétursson, 2005; Norðdahl et. al., 2008). 
Late glacial shorelines in Iceland were formed when a temporary balance was reached between the rise of the sea level and subsidence of the crust, caused by expansion and temporary standstill of the glaciers. In parts of Iceland raised shorelines are found at three distinct altitudes. In the western part shorelines of Bølling age are found at altitude as high as $150 \mathrm{~m}$ a.s.1, shorelines of Younger Dryas age are found at about $60 \mathrm{~m}$ a.s.1., and shorelines of early Preboreal age are found at about $40 \mathrm{~m}$ a.s.l. In the north-eastern part, on Melrakkaslétta, the Bølling shorelines are found at 50-60 m a.s.1., the Younger Dryas shorelines at about $20 \mathrm{~m}$ a.s.1., and the early Preboreal shorelines at $10 \mathrm{~m}$ a.s.l. In other parts of the country usually only two distinct shorelines are found, i.e. of Younger Dryas and early Preboreal age.

In the following chapters a more thorough description of relative sea level changes and environmental changes during the deglaciation of the Icelandic ice sheet is given.

\section{Bølling deglaciation and formation of Marine Limit shorelines}

Relatively warm Atlantic water reached the shelf areas off North Iceland between 18.6-16.3 cal kyrs BP (Table 1;5-6) and the ice sheet retreated from the shelf off West Iceland at 15.0 cal kyrs BP (Table 1;7) (Syvitski et al., 1999; Eiríksson et al., 2000; Andrews et al., 2000; Geirsdóttir et al., 2002). Ingólfsson and Norðdahl (2001) suggested that a rapid rise of global sea level, caused by melting of the large Laurentide, Scandinavian and Barents Sea ice sheets, floated marine based parts of the Icelandic ice sheet and caused its collapse through intensive calving. The shelf off West Iceland was deglaciated at about 15.0 cal kyrs BP (Syvitski et al., 1999), and coastal areas in West Iceland were ice-free but submerged at about 14.7 cal. kyr BP (Table 1;8) (Ingólfsson and Norðdahl, 2001). Marine limit (ML) shorelines in West Iceland occur at 150 and $105 \mathrm{~m}$ a.s.l. at Stóri-Sandhóll and Stóra-Fellsöxl (Fig. 2), respectively, and have been dated between 14.7 and 15.1 cal kyrs BP (Table 1;8-9) (Magnúsdóttir and Norðdahl, 2000; Ingólfsson and Norðdahl, 2001). In Northeast Iceland, the ML shoreline is at 50-60 m a.s.1. on Melrakkaslétta (Fig. 2) and has been dated to about 14.8 cal kyrs BP (Table 1;10) (Pétursson, 1991). In the Bjarkarlundur area in the north-eastern part of Breiðafjörður in Northwest Iceland, Lloyd et al. (2009) reported raised ML shorelines of Bølling age at elevations between 80 and $100 \mathrm{~m}$ a.s.1. Raised shorelines occur up to $70 \mathrm{~m}$ a.s.l. in Southwest Iceland, up to $90 \mathrm{~m}$ a.s.l. in Northwest and North Iceland, and as high as $60 \mathrm{~m}$ a.s.l. in Northeast Iceland. These undated shorelines have tentatively been assigned to the Bølling Chronozone, based on geomorphological and stratigraphical correlations.

Marine sediments of Bølling age are widespread in West and Southwest Iceland (Fig. 2). Fossil mollusc fauna (Macoma calcarea community) contained within these sediments, as well as oxygen isotope ratios in shells, suggest sea surface temperatures similar to the present, indicating relatively warm Atlantic seawater around Iceland in Bølling times (Ingólfsson, 1988).

In Borgarfjörður, West Iceland, a large outlet glacier advanced just after 14.0 cal kyrs BP (Table 1;11). In the lower Borgarfjörður area the glacier overran and deformed marine sediments of Bølling age and formed a spectacular end moraine complex (Ingólfsson, 
1988). This is the only known glacier advance of this age in Iceland. Norðdahl et al. (2008) suggested that this advance might not have been climatically driven but that the Borgarfjörður ice stream surged when the Icelandic ice sheet was being stabilized following its early Bølling collapse.

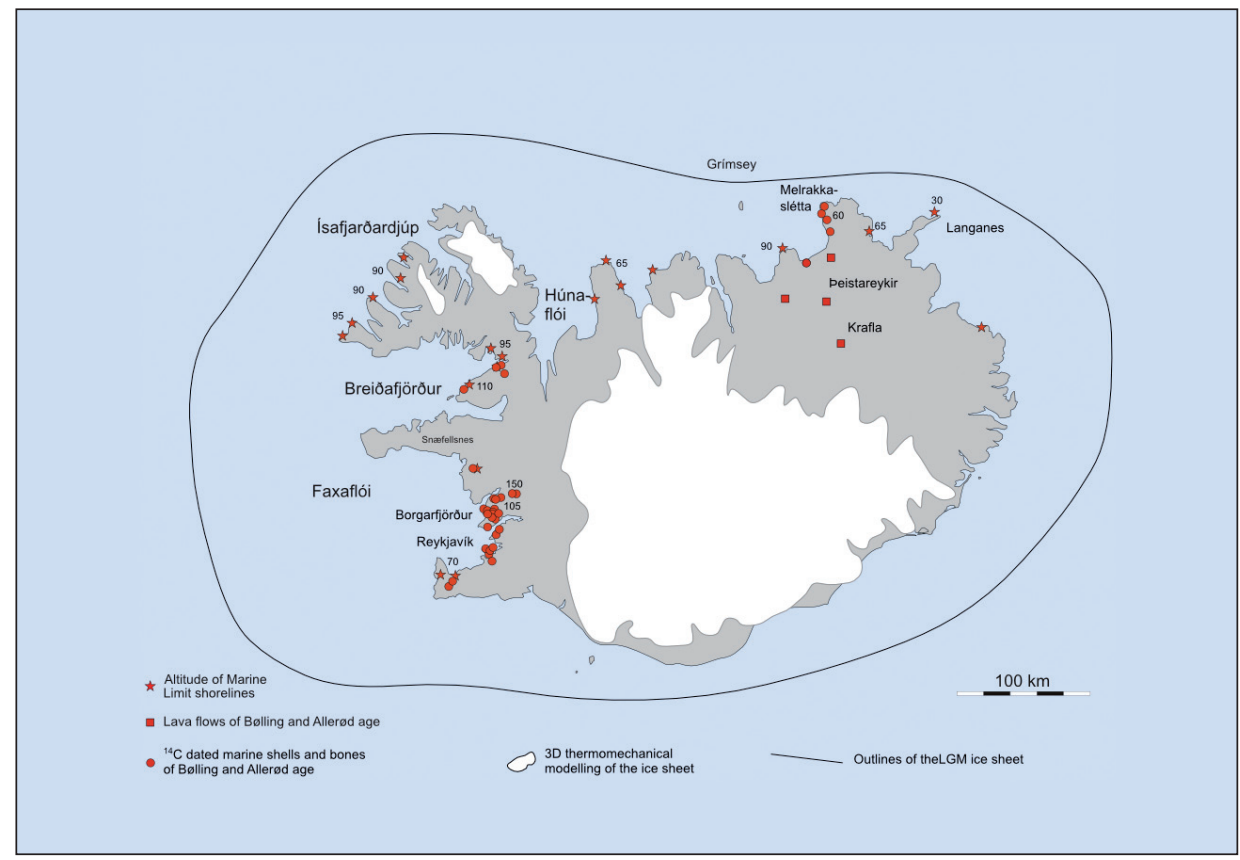

Figure 2. The Icelandic ice sheet after the Bølling deglaciation. (Modified from Norðdahl et al., 2008).

Norðdahl et al. (2008) concluded that the Icelandic ice sheet retreated to positions well inside the present coastline from Southwest to Northeast Iceland in early Bølling times, but coastal areas in East, Southeast and South Iceland were deglaciated somewhat later. The ice sheet was reduced to about $25 \%$ of its LGM size at 13.8 cal kyrs BP (Table 1;12) (Fig. 2). Following this rapid deglaciation and reduction of glacier load on the crust, there was a rapid fall in relative sea level (RSL).

Extensive sub-aerial lava-flows, originating from the Peistareykir Volcano and the Krafla Volcano in North Iceland (Sæmundsson, 1973, 1991; Norðdahl and Pétursson, 2005), show that at least parts of the Northern Volcanic Zone became ice-free in Bølling/ Allerød times (Fig. 2).

At least some of the interior parts of Iceland must have become ice free by this rapid deglaciation and the fast glacio-isostatic recovery influenced in the mantel condition below Iceland, resulting in increased practical melting and a large pulse in volcanic activity in Iceland (Sigmundson, 1991, 2006; Slater et al., 1998; Maclennan et al., 2002; Sigvaldason, 2002; Licciardi et al., 2007). 


\section{Allerød environmental developments}

Fossiliferous marine sediments of Allerød age occur in coastal areas and have mainly been studied in Southwest, West and Northeast Iceland notably in Breiðafjörður, Borgarfjörður and Reykjavík (Fig. 2). Allerød sediments in the Breiðafjörður area contain arctic mollusc species such as Portlandia arctica and foraminifera faunal assemblage of Elphidium excavatum - Casidulina reniforma. Marine shells have been radiocarbon dated to about 13.1 cal. kyr BP (Table 1;13) (Ásbjörnsdóttir and Norðdahl, 1995).

The Allerød marine sediments in the lower Borgarfjörður area show that RSL rose during the earlier part of the Allerød Chronozone. This transgression has been interpreted to signify both rise of eustatic sea level and subsidence of the Iceland crust caused by expansion of the Icelandic ice sheet (Norðdahl and Pétursson, 2005). The sedimentology and mollusc fauna indicate a near-shore marine environment with relatively rapid sedimentation and/or presence of brackish water, most likely due to inflow of glacial melt water (Ingólfsson, 1988). The appearance of arctic mollusc species, Portlandia arctica and Buccinum groenlandicum, towards the end of the Allerød Chronozone, radiocarbon dated to 12.8 cal kyrs BP (Table $1 ; 14$ ), shows that cold water characterized the marine environment in the outer parts of the Borgarfjörður region.

The Fossvogur sedimentary sequence in Reykjavík, deposited close to the transition between the Allerød and the Younger Dryas Chronozones, reveals a history of glacier oscillations and a rise of RSL. The mollusc fauna of the Fossvogur sediments contains boreal species that occur today in the waters around Iceland. A weighted mean of 30 radiocarbon dates (Sveinbjörnsdóttir et al., 1993) suggests deposition at around 12.9 cal kyrs BP (Table $1 ; 15)$. The upper part of the sequence demonstrates increasing proximity to a tidewater glacier and its subsequent retreat in early Younger Dryas times (Geirsdóttir and Eiríksson, 1994). Combined, the Borgarfjörður and Fossvogur data suggest rapid cooling of Southwest Iceland coastal waters close to the Allerød-Younger Dryas transition.

In the Skagi peninsula in North Iceland, pollen, diatom and carbonate analysis on sediments retrieved from Lake Torfadalsvatn, show expansion of grassland/grass tundra in mid-Allerød times, and that shrub and dwarf shrub tundra vegetation was established by the end of the Allerød Chronozone (Rundgren, 1995, 1999). The Lake Torfadalsvatn data show that late Allerød warmest-month temperature may have been as high as $10^{\circ} \mathrm{C}$.

\section{The Younger Dryas glacial and climatic event}

The Icelandic Younger Dryas ice sheet expanded across some of the coastal sites that had been ice-free since the initial Bølling deglaciation. In mouths of fjords and valleys around Iceland, truncated raised shorelines demonstrate both the extent of the marine environment and of glaciers that prevented shorelines to be formed farther inland. The Younger Dryas glacial event is also bracketed by terminal moraine systems and iceproximal delta and sandur deposits. An overview of the Younger Dryas glacier expansion is shown in Fig. 3. 


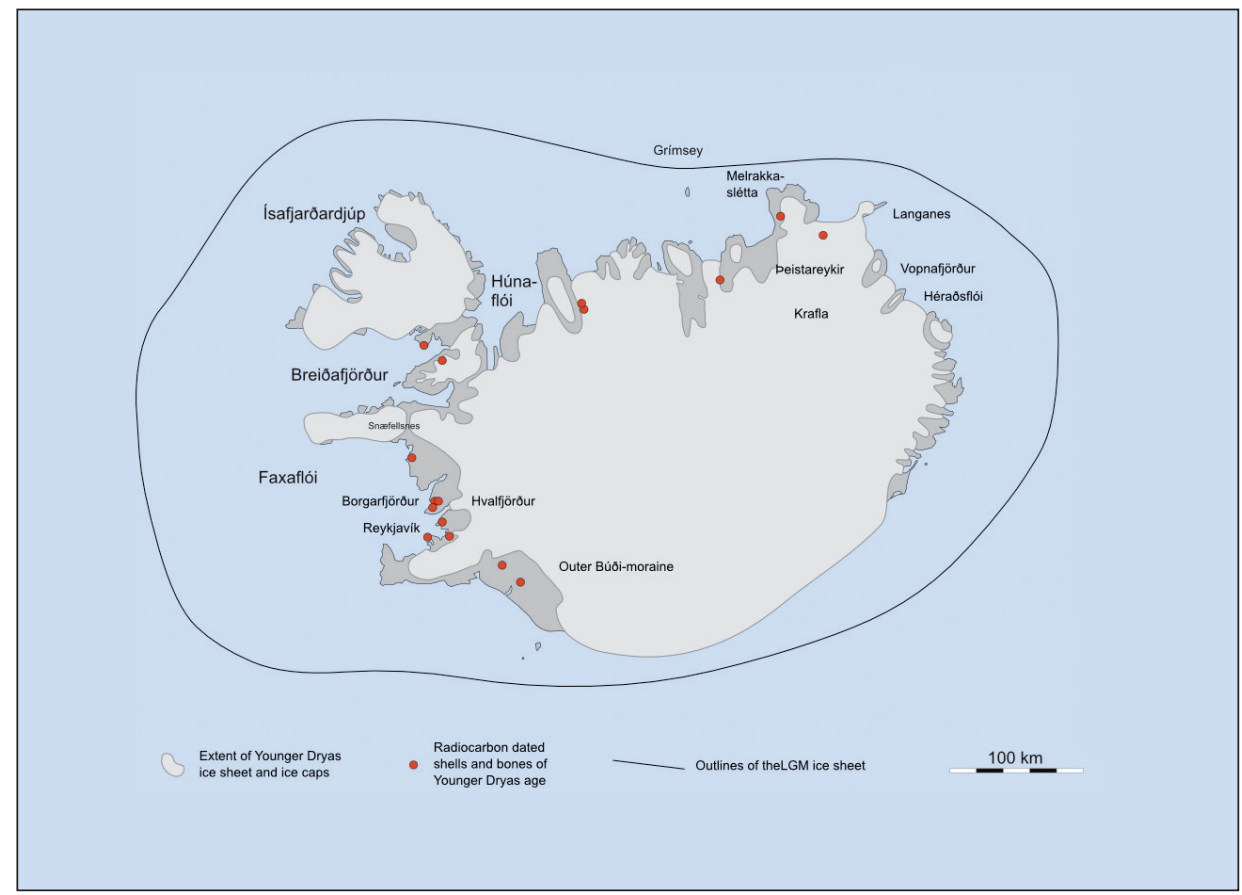

Figure 3. Younger Dryas ice extent on Iceland. (Modified from Norðdahl et al., 2008).

Northeast of Reykjavík, the termination of a Younger Dryas glacier advance is marked by ice-contact deltas and related shoreline features radiocarbon dated to $12.0 \mathrm{cal} \mathrm{kyr}$ BP(Table 1;16) (Ingólfsson et al., 1995), while truncated shorelines show that the glaciers terminated in the Hvalfjörður fjord and tributary valleys in the upper Borgarfjörður area. Truncated shorelines also suggest that there was a Younger Dryas expansion of glaciers in West Central Iceland and along the southern (Breiðafjörður) perimeter of Northwest Iceland (Norðdahl and Pétursson, 2005). Sediment cores retrieved from the Ísafjarðardjúp basin in Northwest Iceland reveal expansion of glaciers into the trunk fjord (Geirsdóttir et al., 2002). Promontories along the western and north-eastern coast of Northwest Iceland remained mostly ice-free at the same time (Hjort et al., 1985).

The Skagi peninsula in North Iceland probably hosted cirque glaciers during the Younger Dryas glacial event, whereas its lowlands in the northern part were ice-free (Ingólfsson et al., 1997). Primary occurrences of the Skógar-Vedde Tephra in ice-lake sediments in Fnjóskadalur show that in Younger Dryas times there were numerous icefree enclaves in North Central Iceland (Norðdahl and Hafliðason, 1992).

A large outlet glacier in the Eyjafjörour fjord probably reached the island of Hrísey (Fig. 3). Younger Dryas raised shorelines in the Öxarfjörður area (11.7 cal kyrs BP) (Table 1;17), which suggest that the ice margin was situated inside the present coastline there, and truncated shorelines suggest that the tip of the Langanes peninsula remained ice-free in Younger Dryas times (Pétursson, 1991; Norðdahl and Hjort, 1995). Truncated shorelines south of the Héraðsflói 
bay in East Iceland suggest that outlet glaciers were grounded in the eastern fjords, while many promontories and headlands remained ice-free (Norðdahl and Einarsson, 2001). In Southeast Iceland, the ice sheet probably extended beyond the present coast.

The Búði moraine marks the Younger Dryas glacier extent inside the present coast of South Central Iceland (Norðdahl and Pétursson, 2005). Recent investigations show that the Búði moraine is complex and composed of two different sets of moraines of different age. The outer set of moraines was formed during a glacier advance preceding the formation of the inner set, that has been dated to 11.2 cal kyrs BP or early Preboreal times (Table $1 ; 18)$, therefore it is thought likely that the outer set of moraines is of Younger Dryas age (Norðdahl et al., 2008). A moraine buried some $20 \mathrm{~m}$ below the surface of the Markarfljót sandur in South Iceland has been correlated with the outer set of the Búði moraines (Haraldsson, 1981).Biostratigraphical data highlighting the Allerød-Younger Dryas-Holocene climate transitions come from sediment cores from Lake Torfadalsvatn in North Iceland (Rundgren, 1995, 1999). They show a rapid climatic cooling at the onset of the Younger Dryas, expressed in sudden fall in the concentration of pollen and reduction in lake productivity. The dominant vegetation at northern Skagi changed from dwarf-shrub tundra to grass tundra, reflecting a shift from mild to cold climatic conditions with low mean summer temperature, indicating perennial sea-ice coverage off North Iceland. The grass tundra on the Skagi peninsula persisted through the Younger Dryas and developed into dwarf-shrub tundra and subsequently into dwarfshrub and shrub tundra after the Younger Dryas-Holocene transition. Sediment core data from the shelf off West and North Iceland have also been interpreted to signify a Younger Dryas cooling (Eiríksson et al., 2000; Jennings et al., 2000).

The Younger Dryas glacial re-advance of the Icelandic ice sheet also saw a vigorous eruption of the Katla Volcano and formation of the basalt-basaltic andesite and rhyolitic Skógar-Vedde Tephra (Norðdahl and Hafliðason, 1992). This tephra is a very important component of Ash zone I found in deep-sea sediments throughout the North Atlantic Ocean and in lacustrine and sub-littoral sediments in Scandinavia and the British Isles (Mangerud et al., 1984; Kvamme et al., 1989; Turney, 1998). The Skógar-Vedde Tephra has been radiocarbon dated on land in Norway to 12.1 cal kyrs BP (Bard et al. 1994) and in sediment cores retrieved from the bottom of the North Atlantic Ocean to 12.1 cal kyrs BP, based on NGRIP Ice core chronology (Hald et al., 2007). Outside Fnjóskadalur in North Iceland primary occurrence of the Skógar-Vedde Tephra has been verified e.g. in cores retrieved from Lake Torfadalsvatn in North Iceland (Björck et al., 1992) and Lake Hestvatn in South Iceland (Harðardóttir et al., 2001).

\section{Early Preboreal glaciation}

Inside the Younger Dryas moraines in Iceland a series of terminal moraines reflect a step-wise retreat of the ice sheet towards the inner part of the country and the highlands.

The outermost post-Younger Dryas moraines, the inner Búði-moraines (Fig. 4) in South Central Iceland were formed during a short lived re-advance of the Icelandic ice sheet at about 11.2 cal kyrs BP. Glaciers in East Iceland also reached the sea in the central 
fjords at 11.2 cal kyrs BP (Table 1;19) (Norðdahl and Einarsson, 2001), whereas a major outlet glacier occupying the lake Lögurinn basin in Fljótsdalur terminated well inside the present coast when RSL was at about 30 m a.s.l. Glaciers in Vopnafjörður terminated in the inner parts of the fjord and raised beaches outside the ice-marginal zone have been dated to 10.9 cal kyrs BP (Table 1;20) (Sæmundsson, 1995). Moraines and other ice marginal features 3-5 km inland of raised beaches at 30-35 $\mathrm{m}$ a.s.l. in the Langanes area delimit the Preboreal extent of the ice sheet (Fig. 4) (Norðdahl and Hjort, 1995), and the ice margin in the Öxarfjörður area was also situated inland of the Preboreal shorelines (Norðdahl and Pétursson, 2005). At 11.1 cal kyrs BP (Table 1;21), the outlet glacier in Eyjafjörður terminated about $50 \mathrm{~km}$ inside its Younger Dryas position, while glaciers in tributary valleys reached the sea close to the present coastline (Figs 3 and 4) (Norðdahl and Pétursson, 2005). A major outlet glacier in Skagafjörður, North Central Iceland, reached the head of the fjord when the Skagi peninsula was mostly ice-free (Ingólfsson et al., 1997). There is a paucity of data on the Preboreal extent of the ice sheet in West Iceland. Glaciers probably reached the sea in the Dalir area, when RSL was at 30-35 m a.s.l., and an outlet glacier terminated in the innermost part of Hvalfjörður when RSL was situated at about $65 \mathrm{~m}$ a.s.l. Outlet glaciers extending from an ice cap situated above the Gláma area in Northwest Iceland reached the sea along the northern shore of Breiðafjörður (Norðdahl and Pétursson, 2005). Large peninsulas as Snæfellsnes in West Iceland, Tröllaskagi and Flateyjarskagi in North Iceland and mountainous areas in East, Southeast and Southwest Iceland probably carried numerous local corry and valley glaciers in early Preboreal times (Norðdahl and Pétursson, 2005).

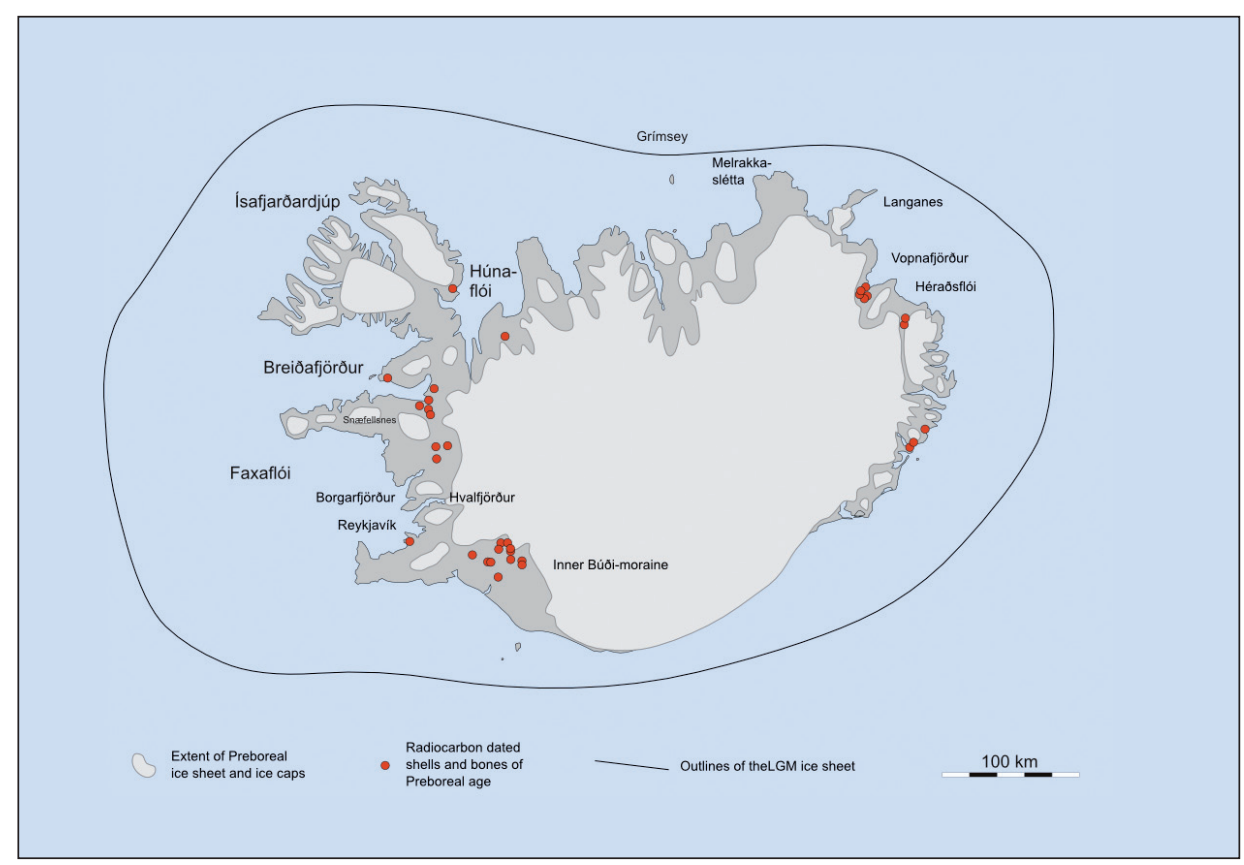

Figure 4. Early Preboreal ice extent on Iceland. (Modified from Norðdahl et al., 2008). 
The spatial difference between the Younger Dryas and early Preboreal ice sheets in Iceland was small except in North Iceland, where major outlet glaciers had retreated $30-50 \mathrm{~km}$ relative to their Younger Dryas positions (Figs 3 and 4). The early Preboreal ice sheet was about 25-20\% smaller than 800 years earlier (Norðdahl et al., 2008). After $11.2 \mathrm{cal}$ kyrs BP the Icelandic ice sheet retreated very rapidly, and at 8.7 cal kyrs BP (Table 1;22) the ice sheet had disintegrated (Kaldal and Víkingsson, 1991) into individual icecaps of similar or little less extent than the present glaciers.

\section{Lateglacial relative sea level changes}

The Icelandic LGM ice sheet had a substantial grounded component (Fig. 1). The initial retreat of the ice sheet was probably controlled by rapidly rising global sea levels due to melting of the large North American, Scandinavian and Barents Sea ice sheet (Fairbanks, 1989, Tushingham and Peltier, 1991), causing the grounding line of the Icelandic ice sheet to move landwards. Because of the sensitivity of the Icelandic crust to variations in glacier load, RSL history closely mirrors post-LGM glacial oscillations (Sigmundsson, 1991; Ingólfsson et al., 1995; Ingólfsson and Norðdahl, 2001; Norðdahl and Einarsson, 2001).

The following compilation of RSL changes in Iceland is mainly based on reviews by Norðdahl and Pétursson (2005) and Norðdahl et al. (2008).

In West Iceland Marine Limit shoreline at about $150 \mathrm{~m}$ a.s.l. was formed at about 14.7 cal kyrs BP (Fig. 5). At 14.0 cal kyrs BP (Table 1;23), RSL was situated close to $50 \mathrm{~m}$ a.s.1., and between 14.0 and $13.4 \mathrm{cal}$ kyrs BP (Table 1;23-24) it had been lowered down to or slightly below the present sea level in Northeast and West Iceland (Pétursson, 1991; Ingólfsson and Norðdahl, 2001). This signifies an extremely rapid isostatic rebound with a rebound half-life between 200 and 300 years, which is confirmed by RSL studies from West and North Iceland (Ingólfsson et al., 1995, Rundgren et al., 1997). Some 13.8 cal kyrs BP, extensive calving along with climatic amelioration, had reduced the Icelandic ice sheet to about 25-20\% of its LGM size (Norðdahl et al., 2008).

Deterioration of the climate in Allerød and Younger Dryas times caused renewed growth of the ice sheet and a glacial expansion with considerable isostatic depression of the crust, and consequently a formation of shorelines now at altitudes as high as $60 \mathrm{~m}$ a.s.l., in Southwest Iceland, dated to about 12.0 cal kyrs BP in West Iceland (Ingólfsson, 1988). The subsequent retreat of the ice margin again caused isostatic uplift and a regression of RSL by up to $40 \mathrm{~m}$ in West Iceland. Early Preboreal glacier expansion and increased glacio-isostatic loading, which culminated at 11.2 cal kyrs BP, induced isostatically and eustatically controlled transgression of RSL by as much as $25 \mathrm{~m}$ and the formation of distinct and extensive shorelines at $40 \mathrm{~m}$ a.s.l. in Southwest Iceland (Ingólfsson et al., 1995; Norðdahl and Pétursson, 2005). The glaciers retreated towards and into the highlands and, in response to reduced glacier load and isostatic uplift, RSL fell below present sea level. At about 10.7 cal kyrs BP (Table 1;25) RSL passed below the $-2.5 \mathrm{~m}$ level in Reykjavík, while minimum position of RSL was reached at about 10.0 cal kyrs BP (Table 1;26), when it was at $-40 \mathrm{~m}$ and peat accumulated at Hraunin (Fig. 5) on the floor 
of the Faxaflói Bay in Southwest Iceland (Ingólfsson et al. 1995). In Eyjafjörður, Central North Iceland, the same trend in RSL changes has been observed (Thors and Boulton, 1991).

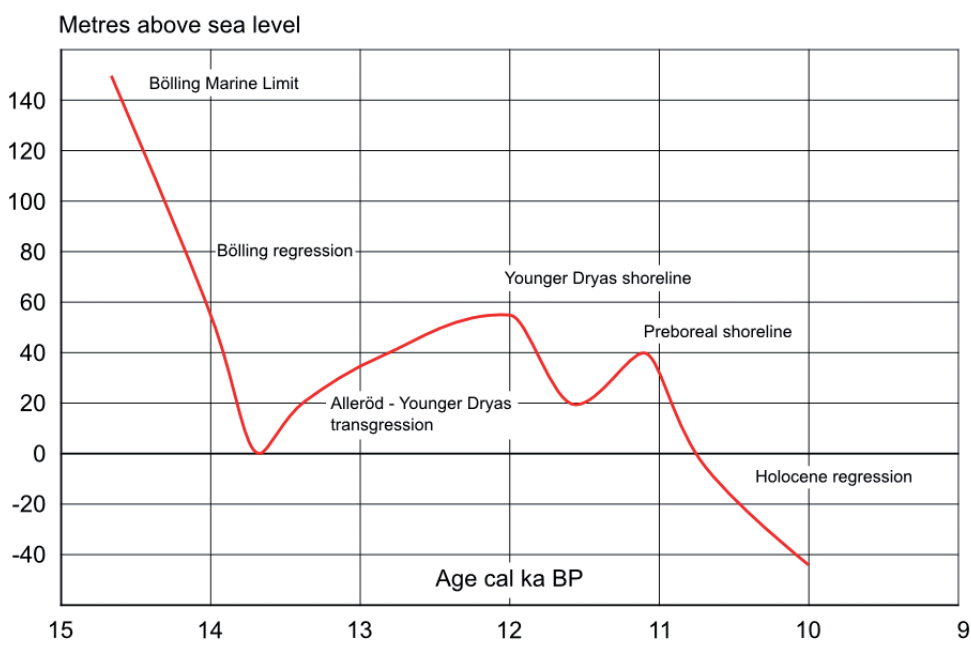

Figure 5. Conceptual relative sea level curve for deglaciation and Holocene in Iceland, based mainly on field data from West and Southwest Iceland. (Modified from Norðdahl and Pétursson, 2005 and Norðdahl et al., 2008).

Since then, sea level changes have been controlled primarily by eustatic changes, causing a continuous rise of sea level from about $-40 \mathrm{~m}$ to present sea level (Fairbanks, 1989; Thusingham and Peltier, 1991; Lambeck et al., 2002).

\section{Summary and conclusions}

Sediment cores retrieved from the shelf around Iceland and sections in coastal areas hold evidence showing that the Icelandic ice sheet increased in size and advanced across the present coastline to reach the edge of the shelf during its LGM maximum extent. Due to late Weichselian and early Holocene extensive and extremely rapid environmental changes, the Icelandic ice sheet retreated and extensive areas became ice-free, areas that subsequently were overridden by the ice sheet during repeated late-glacial glacier advances. These changes in the extent and volume of the ice sheet were accompanied by repeated changes of relative sea level (RSL) between 14.7 and 10.7 cal kyrs BP. Below is a short summary of the main conclusions concerning the post-LGM sea level changes and environmental history of Iceland:

- $\quad$ About or little later than 24.4 cal kyrs BP the Icelandic ice sheet advanced and reached the break of the shelf around Iceland (Fig. 1). The about 1500-2500 m thick ice sheet totally covered the island except a few high coastal mountains with ice-free enclaves. 
- Between 15.0 and 13.8 cal kyrs BP the marine based part of the ice sheet collapsed and rapidly retreated from the shelf and onto present day dry land (Fig. 2). The rapid deglaciation allowed formation of greatly elevated marine limit shorelines in early Bølling times at about 14.7 cal kyrs BP (Fig. 5). Decreased volume and isostatic load of the ice sheet caused accelerated isostatic uplift, and RSL fell and reached a temporary minimum at about 13.8 cal kyrs BP (Fig. 5).

- $\quad$ Between 13.8 and 12.0 cal kyrs BP a climatic deterioration induced positive mass-balance change with increasing ice volume and isostatic lowering during the Allerød, a development that culminated in Younger Dryas time (at about 12.0 cal kyrs BP) when the margin of the ice sheet reached a position close to the coastline of that time (Fig. 3). RSL rose and reached a temporary maximum position at the same time (Fig. 5).

- $\quad$ Between 12.0 and 10.0 cal kyrs BP the ice sheet retreated and subsequently advanced to a distinct Preboreal position (at 11.2 cal kyrs BP) just inside the Younger Dryas position of the ice margin (Figs 3 and 4). During this period RSL first fell and then rose again in phase with variations in the glacio-isostatic load and extent of the ice sheet to finally fall towards and eventually below the altitude of present sea level about 10.7 cal kyrs BP. RSL reached its minimum position of c. $-44 \mathrm{~m}$ in the Faxaflói area at 10.0 cal kyrs BP (Fig. 5).

- $\quad$ Between 10.0 and 8.7 cal kyrs BP the interior highland was deglaciated and the last remnants of the Icelandic ice sheet melted. After $10.0 \mathrm{cal}$ kyrs BP sea level changes were controlled by eustasy alone, a development displaying a more or less continuous rise of sea level from about $-44 \mathrm{~m}$ up to present sea level.

\section{References}

Andrews, J.T., Harðardóttir, J., Helgadóttir, G., Jennings, A.E., Geirsdóttir, A., Sveinbjörnsdóttir, A.E., Schoolfield, S., Kristjánsdóttir, G.B., Smith, L.M., Thors, K., Syvitski, J. 2000. The N and W Iceland Shelf: Insights into Last Glacial Maximum ice extent and deglaciation based on acoustic stratigraphy and basal radiocarbon AMS dates. Quaternary Science Reviews 19, 619-631.

Ásbjörnsdóttir, L., Norðdahl, H. 1995. Götungar í sjávarsetlögum við Mela á Skarðsströnd. In B. Hróarsson, D. Jónsson and S.S. Jónsson (eds.), Eyjar i Eldhafi. Gott mál, Reykjavík, pp. 179-188.

Bard, E., Arnold, M., Mangerud, J., Paterne, M., Labeyrie, L., Duprat, J., Mélières, M.A., Sönstegaard, E., Duplessy, J.C. 1994. The North Atlantic atmosphere-sea surface 14C gradient during the Younger Dryas climatic event. Earth and Planetary Science Letters 126, 275-287.

Björck, S., Ingólfsson, O., Hafliðason, H., Hallsdóttir, M., Anderson, N.J. 1992. Lake Torfadalsvatn: a high resolution record of the North Atlantic ash zone I and the last glacial-interglacial environmental changes in Iceland. Boreas 21, 15-22.

Einarsson, Th. 1967. Zu der ausdehnung der weichselzeitlichen vereisung Nordislands. Sonderveröffentlichungen des Geologischen Institutes der Universität Köln 13, 167-173. 
Eiríksson, J., Knudsen, K.L., Hafliðason, H., Henriksen, P. 2000. Late-glacial and Holocene palaeoceanography of the North Iceland Shelf. Journal of Quaternary Science 15, 23-42.

Fairbanks, R.G. 1989. A 17,000-year glacio-sea level record: influence of glacial melting rates on the Younger Dryas event and deep-ocean circulation. Nature 342, 637-642.

Geirsdóttir, Á., Eiríksson, J. 1994. Sedimentary facies and environmental history of the Lateglacial glaciomarine Fossvogur sediments in Reykjavík, Iceland. Boreas 23, 164-176.

Geirsdóttir, Á., Andrews, J.T., Ólafsdóttir, S., Helgadóttir, G., Harðardóttir, J. 2002. A 36 Ky record of iceberg rafting and sedimentation from north-west Iceland. Polar Research 21, 291-298.

Hald, M., Andersson, C., Ebbesen, H., Jansen, E., Klitgaard-Kristensen, D., Risebrobakken, B., Salomonsen, G.R., Sarnthein, M., Sejrup, H.P., Telford, R.J. 2007. Variations in temperature and extent of Atlantic Water in the northern North Atlantic during the Holocene. Quaternary Science Reviews 26, 3423-3440.

Haraldsson, H. 1981. The Markarfljót sandur area, Southern Iceland: Sedimentological, petrographical and stratigraphical studies. Striae 15, 1-58.

Harðardóttir, J., Geirsdóttir, Á., Sveinbjörnsdóttir, Á. E. 2001. Seismostratigraphy and sediment studies of Lake Hestvatn, southern Iceland: Implications for the deglacial history of the region. Journal of Quaternary Science 16, 167-179.

Håkansson, S. 1983. A reservoir age for the coastal waters of Iceland. Geologiska Föreningens $i$ Stockholm Förhandlingar 105, 65-68.

Hjort, C., Ingólfsson, Ó., Norðdahl, H. 1985. Late Quaternary Geology and Glacial History of Hornstrandir, Northwest Iceland: A Reconnaissance Study. Jökull 35, 9-29.

Hubbard, A., Sugden, J., Dugmore, A., Norðdahl, H., Pétursson, H.G. 2006. A modelling insight into the Icelandic Late Glacial Maxi-mum ice sheet. Quaternary Science Review, 25, 2283 2296.

Ingólfsson, Ó. 1988. Glacial history of the lower Borgarfjördur area, western Iceland. Geologiska Föreningens i Stockholm Förhandlingar 110, 293-309.

Ingólfsson, Ó., Norddahl, H. 2001. High Relative Sea Level during the Bølling Interstadial in Western Iceland: A Reflection of Ice-sheet Collapse and Extremely Rapid Glacial Unloading. Arctic, Antarctic, and Alpine Research 33, 231-243.

Ingólfsson, Ó., Norðdahl, H., Hafliðason, H. 1995. A rapid isostatic rebound in South-western Iceland at the end of the last glaciation. Boreas 24, 245-259.

Ingólfsson, Ó., Björck, S., Hafliðason, H., Rundgren, M. 1997. Glacial and climatic events in Iceland reflecting regional North Atlantic climatic shifts during the Pleistocene-Holocene transition. Quaternary Science Reviews 16, 1135-1144.

Jennings, A., Syvitski, J., Gerson, L., Grönvold, K., Geirsdóttir, A., Harðardóttir, J., Andrews, J.T., Hagen, S. 2000. Chronology and paleoenvironments during the late Weichselian deglaciation of the south-west Iceland shelf. Boreas 29, 167-183.

Jóhannesson, H., Sæmundsson, K., Sveinbjörnsdóttir, Á.E., Símonarson, L.A. 1997. Nýjar aldursgreiningar á skeljum á Reykjanesskaganum. Geoscience Society of Iceland, Spring Meeting 1997, pp. 29-30.

Kaldal, I.,Víkingsson, S. 1991. Early Holocene deglaciation in Central Iceland. Jökull 40, 51-66.

Kvamme, T., Mangerud, J., Furnes, H., Ruddiman, W.F. 1989. Geochemistry of Pleistocene ash zones in cores from the North Atlantic. Norsk Geologisk Tidsskrift 69, 251-272.

Lambeck, K., Yokoyama, Y., Purcell, T. 2002. Into and out of the Last Glacial Maximum: sea-level change during Oxygen Isotope Stages 3 and 2. Quaternary Science Reviews 21, 343-360.

Licciardi, J.M., Kurz, M.D., Curtice, J.M. 2007. Glacial and volcanic history of Icelandic table mountains from cosmogenic ${ }^{3} \mathrm{He}$ exposure ages. Quaternary Science Reviews 26, 1529-1546. 
Lloyd, J.M., Norðdahl, H., Bentley, M.J. Newton, A.J., Tucker, O., Zong, Y. 2009. Lateglacial to Holocene relative sea-level changes in the Bjarkarlundur area near Reykholar, North West Iceland. Journal of Quaternary Science 24, 816-831.

Maclennan, J., Jull, M., McKenzie, D., Slater, L., Grönvold, K. 2002. The link between and deglaciation in Iceland. Geochemistry, Geophysics, Geosystems 3, 1062. (doi: 100.1029/2001GC000282).

Magnúsdóttir, B., Norðdahl, H. 2000. Aldur hvalbeins og fornra fjörumarka í Akrafjalli. Náttúrufraððingurinn 69, 177-188.

Mangerud, J., Andersen, S.T., Berglund, B.E., Donner, J.J. 1974. Quaternary stratigraphy Norden, a proposal for terminology and classification, Boreas 3, 109-126.

Mangerud, J., Lie, S.E., Furnes, H., Kristiansen, I.L., Lömo, L. 1984. A Younger Dryas ash bed in western Norway, and its possible correlations with tephra in cores from the Norwegian Sea and the North Atlantic. Quaternary Research 21, 85-104.

Norðdahl, H. 1991. A review of the glaciation maximum concept and the deglaciation of Eyjafjörður, North Iceland. In J.K. Maizels and C. Caseldine (eds.), Environmental Changes in Iceland: Past and Present, Kluwer Academic Publishers, Dordrecht, pp. 31-47.

Norðdahl, H., Hafliðason, H. 1992. The Skógar tephra, a Younger Dryas marker in North Iceland. Boreas 21, 23-41.

Norðdahl, H., Hjort, C. 1995. Lateglacial raised beaches and glacier recession in the Thistilfjördur - Bakkaflói area, North-eastern Iceland. Jökull 43, 32-44.

Norðdahl, H., Einarsson, Th. 2001. Concurrent changes of relative sea-level and glacier extent at the Weichselian - Holocene boundary in Berufjörður, Eastern Iceland. Quaternary Science Reviews 20, 1607-1622.

Norðdahl, H., Pétursson, H.G. 2005. Relative sea level changes in Iceland. New aspects of the Weichselian deglaciation of Iceland. In C. Caseldine, A. Russel, J. Harðardottir and Ó. Knudsen (eds.), Iceland - Modern Processes and Past Environments, Elsevier, Amsterdam, pp. $25-78$.

Norðdahl, H., Ingólfsson, O., Pétursson, H.G., Hallsdóttir, M. 2008. Late Weichselian and Holocene environmental history of Iceland. Jökull 58, 343-364.

Ólafsdóttir, Th. 1975. Jökulgarđur á sjávarbotni út af Breiðafirði. Náttúrufrææðingurinn 45, 31-36.

Pétursson, H.G., 1986. Kvartergeologiske undersökelser på Vest-Melrakkaslétta, Nordöst Island. Unpublished Cand. Real. thesis, University of Tromsö, Tromsö.

Pétursson, H.G. 1991. The Weichselian Glacial History of West Melrakkaslétta, North-eastern Iceland. In J.M. Maizels and C. Caseldine (eds.), Environmental Changes in Iceland: Past and Present. Kluwer Academic Publishers, Dordrecht, pp. 49-65.

Reimer, P.J., Bard, E., Bayliss, A., Beck, J.W., Blackwell, P.G., Bronk Ramsey, C., Buck, C.E., Cheng, H., Edwards, R.L., Friedrich, M., Grootes, P.M., Guilderson, T.P., Haflidason, H., Hajdas, I., Hatté, C., Heaton, T.J., Hogg, A.G., Hughen, K.A., Kaiser, K.F., Kromer, B., Manning, S.W., Niu, M., Reimer, R.W., Richards, D.A., Scott, E.M., Southon, J.R., Turney, C.S.M., van der Plicht, J. 2013. IntCal13 and MARINE13 radiocarbon age calibration curves 0-50000 years cal BP. Radiocarbon 55, 1869-1887.

Rundgren, M. 1995. Biostratigraphic evidence of the Allerød -Younger Dryas-Preboreal oscillation in Northern Iceland. Quaternary Research, 44, 405-416.

Rundgren, M. 1999. A summary of the environmental history of the Skagi peninsula, northern Iceland, 11,300-7800 BP. Jökull 47, 1-19.

Rundgren, M., Ingólfsson, O. 1999. Plant survival in Iceland during periods of glaciations. Journal of Biogeography 26, 387-396.

Rundgren, M., Ingólfsson, Ó., Björck, S., Jiang, H.,Haflidason, H. 1997. Dynamic sea-level change during the last deglaciation of northern Iceland. Boreas 26, 201-215. 
Sigmundsson, F. 1991. Post-glacial rebound and asthenosphere viscosity in Iceland. Geophysical Research letters 18, 1131-1134.

Sigmundsson, F. 2006. Iceland geodynamics: crustal deformation and divergent plate tectonic. Springer-Praxis, Chichester.

Sigvaldason, G.E. 2002: Volcanic and tectonic processes coinciding with glaciation and crustal rebound: An early Holocene rhyolitic eruption in the Dyngjufjöll volcanic centre and the formation of the Askja caldera, north Iceland. Bulletin of Volcanology 64, 192-205.

Slater, L., Jull, M., Mckenzie, D., Grönvold, K. 1998. Deglaciation effects on mantle melting under Iceland: results from the northern volcanic zone. Earth and Planetary Science Letters 164, 151-164.

Spagnolo, M., Clark, C.D. 2009. A geomorphological overview of glacial landform on the Iceland continental shelf. Journal of Maps 5, 37-42.

Stuvier, M., Reimer, P.J. 1993. Extended ${ }^{14} \mathrm{C}$ database and revised CALIB radiocarbon calibration program. Radiocarbon 35, 215-230.

Sveinbjörnsdóttir, Á.E., Eiríksson, J., Geirsdóttir, Á., Heinemeier, J., Rud, N. 1993. The Fossvogur marine sediments in SW Iceland - confined to the Allerød /Younger Dryas transition by AMS ${ }^{14} \mathrm{C}$ dating. Boreas 22, 147-157.

Syvitski, J., Jennings, A.E., Andrews, J.T. 1999. High-resolution Seismic Evidence for Multiple Glaciation across the Southwest Iceland Shelf. Arctic, Antarctic, and Alpine Research 31, 50-57.

Sæmundsson, K. 1973. Straumrákaðar klappir í kringum Ásbyrgi. Náttúrufraeðingurinn 43, 52-60.

Sæmundsson, K. 1991. Jarðfræði Kröflukerfisins. In A. Garðarsson and Á. Einarsson (eds.), Náttúra Mývatns, Hið íslenska náttúrufræðifélag, Reykjavík, pp. 25-95.

Sæmundsson, Th. 1995. Deglaciation and shoreline displacement in Vopnafjörður, North-eastern Iceland. Lundqua Thesis 33, 1-106.

Thors, K., Boulton, G.S. 1991. Deltas, spits and littoral terraces associated with rising sea level: Late Quaternary examples from Northern Iceland. Marine Geology 98, 99-112.

Thors, K., Helgadóttir, G. 2014. Hryggir í Lónsdjúpi. Náttúrufraeðingurinn 84, 43-48.

Turney, C.S.M. 1998. Extraction of rhyolitic component of Vedde microtephra from minerogenic lake sediments. Journal of Paleolimnology 19, 199-206.

Tushingham, A.M., Peltier, W.R. 1991. Ice-3G: a new global model of Late Pleistocene deglaciation based upon geophysical prediction of post-glacial relative sea level change. Journal of Geophysical Research 96, 4497-4523. 